\title{
Superconductivity spurs Japanese plan for NMR research
}

Tokyo. A group of Japanese chemists and biologists, backed by the Science and Technology Agency (STA), has drawn up ambitious plans to establish a state-ofthe-art centre for using nuclear magnetic resonance (NMR) to study the structure and function of proteins. The proposed centre would not only use the most advanced NMR machines available, but also aim to develop new NMR technology using high-temperature superconductors.

The group is led by Akiyoshi Wada, former dean of science at Tokyo University, who is said to have won backing at the highest level in STA. As a result, the first funds for a feasibility study are likely to be included in the agency's budget request for fiscal year 1997 (which starts on 1 April), due to be submitted at the end of August. In Japan, commitment to such a study almost invariably leads to implementation of the project.

The centre, or 'NMR Park' as it is called, would initially use 750-800 $\mathrm{MHz}$ NMRs, the most powerful machines available which use conventional superconducting magnets. But, in addition to carrying out research with these machines, another aim of the park would be to develop much higher resolution 1 Ghz NMRs, using coils of both conventional and high-temperature (high- $T_{\mathrm{c}}$ ) superconductors.

Japan is advanced in the development of high- $T_{\mathrm{c}}$ superconducting wires, and is in a strong position to develop such coils. But Yoji Arata, a former professor of physical chemistry at Tokyo University who is backing the project, admits that it may take some time before it is possible to achieve the necessary resolution and stability with high- $T_{\mathrm{c}}$ coils.

Supporters of the park want it to be a truly international centre drawing scientists from around the world, much like Japan's 'Photon Factory', a synchrotron facility in Tsukuba science city. Arata will host an international symposium for structural biologists and NMR specialists later this month in Tsukuba at which he hopes to enlist support and advice from overseas leaders in the field.

Funds for the project would be channelled through the Institute of Physical and Chemical Research (RIKEN), which is expected formally to endorse the project later this month. A site for the park has not yet been chosen, and it will take until at least the end of this year before STA can set a firm budget. But a figure of $¥ \mathbf{5 0}$ billion (US\$500 million) for the overall cost of the park is being widely quoted.

David Swinbanks

\section{'Race and IQ' psychologist in inquiry over teaching conduct}

London. The University of Edinburgh has launched an inquiry into the teaching conduct of Chris Brand, a lecturer in psychology at the university, and author of a controversial book on race and intelligence that was withdrawn last month by its US publishers, John Wiley and Sons.

The inquiry - seen by Brand as signalling the encroachment of 'political correctness' in British universities - will focus on his teaching methods, following complaints from students that he made them feel "uncomfortable" during classroom discussions with his contentious views on race, gender and intelligence.

In his book, The $g$ factor: General Intelligence and its Implications, Brand claims that the genetic component in intelligence outweighs environ- Brand: defiant of mental influences, student boycott. and repeats the view that blacks in the United States obtain lower average IQ scores than whites.

The publishers withdrew the book after newspaper interviews quoted Brand as having described feminism as a 'menace' and suggesting that single mothers ought to mate with males of a higher IQ. A statement from the publishers described Brand's assertions as "repellent" (see Nature 381, 10; 1996).

The inquiry was announced at a press conference by Sir Stewart Sutherland, principal of the university. It will be carried out by Neil MacCormick, dean of social sciences and professor of law at the university, who will report to the principal next week.

In a statement, Sutherland, a former vice chancellor of the University of London, said he had "no hesitation" in saying that "the large majority of my colleagues in the university do not share conclusions on eugenics apparently held by Mr Brand". Many of Brand's students continue to boycott his classes. Sutherland also announced plans for a seminar later in the term, to include speakers "with various viewpoints on intelligence and the relative importance of heredity and environmental factors".

Brand describes the inquiry as a "side issue" that is detracting attention from "the suppression" of his book. The question of his teaching methods, he says, would not have arisen were it not for the publicity surrounding the book. He vigorously defends his teaching style which he describes as "frank and relaxed".

"Students are simply the victims of the religious hysteria of our times", he says. "This is why they find everything that touches on their prejudices to be insensitive. If in deference to 'sensitivity', I draw a veil [on controversial issues], they'll find me incomprehensible."

Meanwhile, Brand continues to respond to the controversy he has generated with vigour. Indeed, the worldwide publicity generated by Wiley's decision to distance itself from the book appears to have had unexpectedly favourable consequences. The lecturer claims to have several offers to publish the book, and says any new publisher is likely to print and sell many more than the 2,000 copies planned by Wiley.

Brand has already demanded that Wiley pay US\$75,000 for a relaunch. The alternative, he states, is for Wiley to apologize publicly, resume publication and supply psychology libraries worldwide with a free copy of the book. The publishers, according to Brand, have merely offered to provide him with unjacketed copies of the book, and to reassign the copyright.

Brand's decision to differentiate his position on race and intelligence from the withdrawal of the book is a calculated one. It has put many of his scientific opponents, as well as his university, in the position of having to support the right to 'academic freedom'. Indeed, many would prefer his book to be published so that his 'scientific' arguments could be held up to academic scrutiny.

The book itself presents a chain of assertions: that IQ is a measure of intelligence; that intelligence boils down to a measure of the speed of apprehension, that intelligence is largely governed by genetic factors, and that all this has implications that should be taken into account by society, particularly in formulating education policy.

Critics have challenged Brand's position by attacking the assertions he makes to hold it up. For example, Nicholas MacIntosh, professor of experimental psychology at the University of Cambridge, who reviewed the book last week (see Nature, 381, 33; 1996), says that the least academically sound of his assertions is that the $\mathrm{g}$ factor - for 'general intelligence' - can be reduced to a measure of speed of apprehension.

MacIntosh says that Wiley's response was unwise. "I don't think what they find offensive is new", he says. "On the whole I believe that academics ought to be able to publish what they believe in." Wiley declines to add to a statement issued when the book was withdrawn: "John Wiley Ltd does not want to support these views by disseminating them or be associated with a book that makes assertions that we find repellent."

Ruth Bell \& Ehsan Masood 